\title{
EL DERECHO AL CUMPLIMIENTO ESPECÍFICO DE LA OBLIGACIÓN DE HACER EN LA DOCTRINA ESPAÑOLA DEL SIGLO XIX ANTERIOR A LA CODIFICACIÓN CIVIL
}

[The Right to Specific Performance of the Obligation to do in the Spanish Doctrine of the 19th Century, Before the Codification of the Civil Law]

\author{
Gonzalo Severín Fuster* \\ Pontificia Universidad Católica de Valparaíso
}

\begin{abstract}
RESUMEN
El trabajo da cuenta de cuál era la aproximación de la doctrina española, en el período inmediatamente anterior a 1889 , a la idea de que el acreedor de una obligación de hacer tiene derecho a obtener el cumplimiento específico de esa obligación. Se busca demostrar: i) que la idea de que el acreedor tiene derecho al cumplimiento específico de la obligación de hacer es una idea discutida en la doctrina civil española del siglo XIX; ii) que los argumentos que sirven tanto para negar como para justificar la existencia de un derecho al cumplimiento específico del acreedor se apoyan, principalmente, en la existencia de vías procesales de apremio; y iii) que, debido a lo anterior, las
\end{abstract}

\begin{abstract}
This work accounts for the approach of the Spanish doctrine in the period right before 1889 , regarding the idea that the creditor of an obligation to do has the right to enforce the specific performance of said obligation. We seek to demonstrate that: $i$ ) the idea that the creditor has the right to the specific performance of the obligation to do is an idea debated in the Spanish civil doctrine of the $19^{\text {th }}$ century; ii) the arguments used to both deny and justify the existence of a right of the creditor to specific performance are mainly based on the existence of procedural and coercion ways; and iii) that, due to the foregoing, the solutions adopted by the Spanish law on civil proce-
\end{abstract}

RECiBiDO el 18 de mayo y ACEPTADO el 30 de julio de 2015

* Profesor asociado de derecho civil en la Facultad de Derecho de la Pontificia Universidad Católica de Valparaíso. Máster en Derecho empresarial y doctor en derecho por la Universidad Autónoma de Madrid. Dirección postal: Facultad de Derecho, Avenida Brasil 2950, Valparaíso, Chile. Correo electrónico: gonzalo.severin@ucv.cl. En este artículo, por regla general se ha modernizado la ortografía. 
soluciones adoptadas por las Leyes de enjuiciamiento civil que vieron la luz durante el siglo XIX inciden, de manera importante, en la comprensión del Derecho sustantivo al cumplimiento específico de la obligación de hacer.

\section{Palabras Clave}

Obligación de hacer - Cumplimiento específico - Apremio. dure created during the $19^{\text {th }}$ century have a significant influence in understanding the substantive law regarding the specific performance of the obligation to do.

\section{KEYWORDS}

Obligation to do-Specific performance - Coercion.

\section{INTRODUCCIÓN}

Este trabajo tiene por finalidad dar cuenta de cuál era la aproximación del derecho español, en el período inmediatamente anterior a la entrada en vigor del Código Civil (1889), a la idea de que el acreedor de una obligación de hacer tiene derecho a obtener el cumplimiento específico de esa obligación. Para abordar esta cuestión, en este trabajo se analiza, principalmente, la doctrina española del siglo XIX ${ }^{1}$.

${ }^{1}$ Esa es, probablemente, la mejor forma de obtener información sobre un aspecto determinado del derecho civil español antes de la entrada en vigor del Código Civil. Ello porque, como es ampliamente sabido, a comienzos del siglo XIX el Derecho civil vigente en España se encuentra recogido en varias recopilaciones, lo que dificulta enormemente el conocimiento del Derecho positivo vigente: el "Ordenamiento de Alcalá" (1348); la compilación de leyes conocida como "Ordenanzas reales" y como "Ordenamiento de Montalvo" (1484); las "Leyes de Toro" (1505), y la Nueva Recopilación (1567); y además, subsidiariamente, siguen vigente los fueros particulares y las Partidas. Por tanto, a comienzos del siglo XIX, el Derecho español se caracterizaba por un estado de dispersión normativa, era un "intrincado laberinto" [así lo expresa Sempere y Guarinos, recogiendo el juicio que, en su momento, hiciera el Colegio de Abogados de Madrid sobre el estado de la legislación española [SEMPERE y Guarinos, Juan, Historia del derecho español (Madrid, Imprenta Nacional, 1822), I, p. 388)]. Ese estado de dispersión normativa es lo que, entre otros factores, explica el "ideal codificador [que] se hará sentir especialmente en la España del siglo XVIII" [De Castro y Bravo, Federico. Derecho civil de España (Madrid, Instituto de Estudios Políticos, 1955), I, p. 194]; y es lo que explica la publicación de la Novísima Recopilación en el año 1805 [así se expresa en la Real Cédula sobre la formación y autoridad de esta Novisima Recopilación de las Leyes de España, inserta al comienzo de la Novísima Recopilación, especialmente, pp. xlv-xlviii]. No obstante, la sanción de la Novísima Recopilación no sólo no superó ese estado de dispersión normativa, sino que lo acentuó. Así lo puso de relieve Francisco Martínez Marina en un ensayo titulado Ensayo histórico-crítico sobre la antigua legislación y principales cuerpos legales de los reynos de León y Castilla: "este año [...] se acaba de publicar [...] la Novísima Recopilación [...] obra más completa que toda las de su clase [...] y que carecería de muchos defectos considerables que se advierten en ella, anacronismos, leyes oportunas y superfluas, erratas y lecciones mendosas [...] si la precipitación con que se trabajó en esta grande obra, por ocurrir a la urgente necesidad de su edición, hubiera dado lugar a un prolixo [sic] examen y comparación de sus leyes con las fuentes originales de donde se tomaron" [(Madrid, Imprenta de la hija de Joaquín Ibarra,1808), p. 398]. El propio Martínez, instado a dar razón de las críticas a la Novísima Recopilación, publicó años más tarde otra obra en la que da cuenta de los anacronismos, repeticiones, errores y otros defectos que se hallaban en la Novísima Recopilación [Martínez Marina, Francisco, Juicio crítico de la Novísima Recopilación [(Madrid, 
El estudio tiene por finalidad demostrar lo siguiente: i) que la idea de que el acreedor tiene derecho al cumplimiento específico de la obligación de hacer es una idea discutida en la doctrina civil española del siglo XIX; ii) que los argumentos que sirven tanto para negar como para justificar la existencia de un derecho al cumplimiento específico del acreedor se apoyan, principalmente, en la existencia de vías procesales de apremio; y iii) que, debido a lo anterior, las soluciones adoptadas por las Leyes de enjuiciamiento civil que vieron la luz durante el siglo XIX (la primera de 1855; la segunda de 1881) inciden de manera importante en la comprensión del derecho sustantivo al cumplimiento específico de la obligación de hacer.

La exposición se divide en dos partes. La primera tiene por objeto ilustrar las distintas opiniones de los autores. La segunda parte intenta ofrecer una explicación para esa discordancia, a partir de los distintos argumentos propuestos por los autores.

\section{LAS DISTINTAS POSICIONES DE LOS AUTORES}

1. La posición que niega la posibilidad de compeler al deudor al cumplimiento de una obligación de hacer.

Al tratar los efectos de las obligaciones, algunos autores del siglo XIX distinguen entre obligaciones de dar y obligaciones de hacer, poniendo de relieve que en las obligaciones de hacer el acreedor no puede compeler al deudor a ejecutar la prestación debida. Esta es, por ejemplo, la opinión de Gómez de la Serna y de Montalbán (1841): "La obligación de hacer o de no hacer en caso de inejecución, para evitar la violencia que se cometería compeliendo a alguno a un hecho, se resuelve en otra de daños e intereses" 2 . En el mismo sentido, se pronuncia Del Viso (1860): "La naturaleza de la obligación de dar es tal, que, si lo exige el acreedor, ha de llevarse precisamente a efecto en los términos en que se pactó; para lo cual podrá reclamarse la intervención de la pública autoridad, utilizando para ello los medios de la vía ejecutiva o de apremio, o el reintegro, restitución o el desaucio [sic], según fuere la materia de la obligación [...] no sucede asi en la obligación relativa a hacer o de prestar algún servicio [...] en la obligación de hacer, si uno que se comprometió a prestar algún servicio se negase absolutamente a ello, como no hay fuerza humana que pueda obligarle a ejecutar su empeño, y no es justo que el acreedor quede perju-

Imprenta de don Fermín Villalpando, 1820)]. Si bien en la Constitución (estatuto) de Bayona hay una referencia a un Código Civil, la idea de codificar el Derecho civil, en el siglo XIX, tiene su más importante reflejo en la Constitución de Cádiz, pues, como algún autor ha planteado, "no puede entenderse significativo al respecto la Carta de Bayona, con su referencia a un Código Civil, como tampoco el Código promulgado por José Napoleón, pues, eran normas impuestas por el invasor [...] la verdadera idea de la codificación se afirma en Cádiz, con la Constitución de 1812" [FERnÁndez Rodríguez, Antonio, Grandes directrices y principios informadores del Código Civil. Estimación conjunta, en Ministerio DE JustiCIA, El centenario del Código Civil en el Tribunal Supremo (Madrid, Centro de Publicaciones, 1989), p. 69].

${ }^{2}$ Gómez de la Serna, Pedro - Montalbán, Juan Manuel, Elementos del derecho civil y penal de España (1 ${ }^{a}$ edición, Madrid, s. l., 1841), II, pp. 18-19. El mismo texto se conserva en las ediciones posteriores (así, por ejemplo, en la 7a edicióbn, Madrid, s. 1., 1865, II, p. 173). 
dicado por haber faltado el deudor a lo pactado, las leyes han dispuesto otro modo de subsanar estos perjuicios [...]"3.

Otros autores que se pronuncian en este mismo sentido, son, por ejemplo, Verlanga Huerta $(1843)^{4}$ y Escriche $(1847)^{5}$.

2. La posición que admite la posibilidad de compeler al deudor al cumplimiento de una obligación de hacer.

Otros autores, en cambio, parecen sostener que sí es posible compeler al deudor a ejecutar una obligación contractual consistente en un hacer. No obstante, se observan, dentro de esta línea, dos aproximaciones diversas.

Algunos autores simplemente se limitan a afirmar el derecho del acreedor a compeler al deudor al cumplimiento. Así, por ejemplo, Sala (1803), aunque sólo afirma ello en relación con los contratos "innominados" ". También en este sentido

${ }^{3}$ Del Viso, Salvador, Lecciones elementales de historia y de derecho civil, mercantily penal de España (Valencia, Imprenta de José Mateo Garín, 1860), parte 2a tratado 3º pp. 63-64. Del Viso expresa que las leyes conceden al acreedor la posibilidad de "utilizar los medios siguientes: [...] hacer que se ejecute la cosa a costa del deudor si este no quisiese hacerla, o si la hubiera hecho contraviniendo en el modo a lo que se hubiera pactado, hacer que se ejecute de nuevo, obligándole a la destrucción de lo mal hecho.l [...] no haciendo uso de este medio, podrá pedir la indemnización de daños y abono de intereses que las leyes conceden en general a los contrayentes por la inejecución del contrato o tardanza en su cumplimiento", relacionando esas vías con el artículo 1008 Pyto. CC. 1851 (Lecciones, parte 2a, tratado $3^{\circ}$, pp. 64). El artículo 1088 Pyto.CC. 1851 señalaba: "Si el obligado a prestar algún servicio que consista en hacer alguna cosa, no lo hiciere, se mandará ejecutar a su costa./Esto mismo se observará si lo hiciere contraviniendo en el modo a lo pactado; y podrá además decretarse la destrucción de lo mal hecho".

4"Ninguno puede ser obligado ni forzado á hacer lo que no se quiere. La promesa ú la obligación de hacer se resuelve desde entonces, necesariamente en la indemnización del perjuicio causado por el refractario, y de la ganancia que haya podido hacer la otra parte. No puede, pues, emplearse la fuerza sino para forzar al refractario a pagar esta indemnización, denominada daños y perjuicios" [Verlanga Huerta, Fermin, El derecho civil universal por aphorismos (Madrid, Imprenta de Tenes, 1843), p. 68, al explicar el aforismo "nemo potest praecise cogi ad factum"].

5 "La obligación de hacer o no hacer alguna cosa se reduce a la obligación de daños y perjuicios cuando el deudor se resiste a ejecutarla, porque nadie puede ser forzado precisamente a un hecho, aunque pueda serlo a la dación o entrega de una cosa, pues de otro modo quedaría infringida la libertad natural del hombre y se le sujetaría a cierta especie de servidumbre [...] de aqui el axioma de derecho: 'nemo potest praecise cogi ad factum"' [EsCRICHE, Joaquín, Diccionario razonado de legislación y jurisprudencia ( $3^{\text {a }}$ edición, Madrid, Librería de la Sra. Viuda e hijos de don Antonio Calleja, editores, 1847), s.v.: "hecho"]. Y en otro lugar, señala: "toda obligación de hacer o no hacer se reduce a la satisfacción de daños y perjuicios, en caso que el deudor no quiera ejecutarla [...] si yo me obligué, pues, a hacerte una pintura, no se me podrá obligar a ejecutar mi empeño y por consiguiente mi obligación habrá de resolverse en daños y perjuicios [...] puede, no obstante, autorizarse al deudor, en caso de inejecución, para que haga ejecutar el mismo al obligación a expensas del deudor: si un arquitecto por ejemplo se ha obligado á edificarme una casa, no puedo yo compelerle é edificarla por sí mismo, pero podré hacer que otro la edifique á su costa" [ibíd.; s.v. "obligación de hacer o no hacer"].

6"El que cumplió por su parte tiene derecho de escoger, o bien apremiar al otro que lo cumpla por la suya, o que pague los perjuicios que le ha ocasionado de no cumplirlo" [SALA, Juan, Ilustración del derecho real de España (Valencia, Imprenta de Joseph de Olga, 1803), p. 237]. La afirmación viene precedida por una referencia al objeto y causa de la obligación, referida a los contratos innominados: "y este dar o hacer es la causa de obligar que hemos expresado" (ibíd., p. 237). Sin 
se pronuncia García Goyena (1852), quien, a diferencia de Sala, afirma el derecho del acreedor a compeler al deudor al cumplimiento de forma general, es decir, para toda obligación de hacer (y no sólo respecto de los contratos innominados) ${ }^{7}$.

Otros, en cambio, tras también afirmar como principio que el acreedor tiene derecho a compeler al deudor al cumplimiento de la obligación de hacer, a través del uso de vías de apremio, matizan la afirmación, indicando de inmediato que, en caso que no sea posible obtener el cumplimiento por esa vía, el deudor debe entonces el id quod interest [así, por ejemplo, Rodríguez $(1861)^{8}$ y Gutiérrez Fernández (1869) $)^{9}$; o bien, indicando que podrá entonces mandarse a ejecutar la obligación a costa del deudor, si ello conviene al acreedor [así, por ejemplo, Falcón $\left.(1878)^{10}\right]$.

\section{UNA POSIBLE EXPLICACIÓN DE LA DISCORDANCIA ENTRE LOS AUTORES}

Es razonable sugerir que son dos los factores que permiten explicar la discrepancia que, en relación con la posibilidad de compeler al deudor al cumplimiento de la obligación de hacer, se observa entre los autores españoles del siglo XIX. Por un lado, el distinto derecho sustantivo de referencia. Por otro lado, la existencia

que luego se haga ninguna distinción entre "el dar" o "el hacer" a la hora de afirmar este derecho de opción del acreedor entre apremiar al deudor o solicitar la indemnización de daños.

${ }^{7}$ García Goyena lo afirma así, a propósito del artículo 1008 Pyto. CC. 1851, recalcando la diferencia que existía entre lo dispuesto en ese artículo y el derecho español vigente a la época. En efecto, tras referirse brevemente al derecho francés (según el cual, la obligación de hacer se convierte en indemnización de daños, artículo 1142 Code), García Goyena explica el derecho vigente, señalando que "nuestras leyes 12, título 11, Partida 5 y 5, título 27, Partida 3 están más claras: Develo apremiar (el Juez) que lo faga assi como fue puesto, é lo prometió" [GARCÍA Goyena, Florencio, Concordancias, motivos y comentarios del Código Civil español (Madrid, imprenta de la Sociedad tipográfica-editorial, 1852), III, pp. 46-47].

${ }^{8}$ "La obligación de hacer que consiste en un hecho personal debe cumplirse lo mismo que se haya contraido, bajo igual pena, y la de pagar cierta multa, si asi se ha estipulado: pero como ninguno puede ser obligado á que practique un hecho nudo, como el pintar el cuadro, u otro semejante; se compelerá al que haya contraído esta responsabilidad, de la manera posible; y en el caso de absoluta negativa, se le condenará á que abone al acreedor lo que le hubiese interesado la prestación del hecho objeto del convenio" [RODRíguEZ, Juan María, Elementos de derecho civil, penal y mercantil de España (Madrid, Imprenta de T. Fortanet, 1861), I, p. 361].

${ }^{9}$ Este autor admite la posibilidad de apremiar al deudor de un "hecho nudo, que interesa al acreedor se practique por el mismo que lo prometio", aunque luego matiza que, "si a pesar de ello no se pudiere conseguir, se abonará el quod interest" [GuTIÉRREZ FernÁNDEZ, Benito, Códigos o estudios fundamentales sobre derecho civil español, tratado de las obligaciones (Madrid, Imprenta de la Sra. V. e hijas de don Antonio Peñuelas, 1869), IV, pp. 55-56].

${ }^{10 " E l ~ q u e ~ s e ~ o b l i g o ́ ~ a ~ h a c e r ~ d e b e ~ c u m p l i r ~ p e r s o n a l m e n t e ~ l o ~ p a c t a d o ~ y ~ p u e d e ~ s e r ~ c o m p e l i d o ~ j u d i c i a l-~}$ mente a ejecutarlo [aquí, va en nota la cita a Partidas V,11,13]. Si se negare todavía a ejecutarlo podrá mandarse a ejecutar a su costa, siendo esto posible conviniendo al acreedor [ahora se cita el artículo 1008 del "Proyecto de Código"; referencia que debe entenderse hecha al Proyecto de Código Civil de 1851]. Solo cuando la obligación es imposible se convierte la obligación en otra de abonar daños y perjuicios" [FALCÓN Y OzCOIDI, Modesto, Exposición doctrinal del derecho civil español, común y foral: según las leyes escritas, la jurisprudencia de los tribunales y la opinión de los escritores (Salamanca, Establ. Tipográfico de D. Vicente Oliva,1878, t. 2), p. 446]. 
y naturaleza de ciertas vías procesales, para apremiar al deudor al cumplimiento de la obligación.

\section{El derecho sustantivo de referencia.}

Como es sabido, durante el siglo XIX se vive en España un proceso de reivindicación del derecho "nacional", especialmente frente al ius commune (al que se denomina también, simplemente, "derecho romano") que había sido, hasta la segunda mitad del siglo XVIII, el derecho de referencia en el ámbito académico universitario. Ahora bien, esa atención preferente que comienza a prestarse al derecho español, frente al romano, no significa, sin embargo, que se prescinda absolutamente del estudio del derecho romano, puesto que es con éste que el derecho español suele contrastarse ${ }^{11}$. Pues bien, un primer factor que permite explicar la diversidad de opiniones sobre el derecho al cumplimiento específico de la obligación de hacer es, precisamente, el derecho sustantivo de referencia: mientras que los autores que niegan el derecho al cumplimiento específico de la obligación de hacer parecen tomar como referencia el derecho romano (el ius commune), quienes afirman la posibilidad del cumplimiento específico de la obligación de hacer se fundan, en cambio, en el derecho español ("nacional" o "patrio"), principalmente, en ciertas leyes de las Partidas.

a) Los argumentos de la posición que niega la posibilidad de compeler al deudor al cumplimiento específico. Lo primero que conviene apuntar, es que la afirmación que realiza una parte de la doctrina española del siglo XIX, en el sentido de que no es posible compeler al deudor al cumplimiento de la obligación de hacer, no suele fundarse en argumentos de texto, sino en argumentos de otro tipo, tales como el respeto a la libertad personal del deudor (así, por ejemplo, Gómez de la Serna y Montalbán) o en la imposibilidad práctica de obtener el cumplimiento de estas obligaciones por la fuerza (así, por ejemplo, Del Viso) ${ }^{12}$. Esos argumentos, como resulta evidente, corresponden a la aproximación tradicional del ius commune a la cuestión del cumplimiento específico de la obligación de hacer, aproximación que, como es sabido, se terminó expresando a través del conocido aforismo "nemo potest praecise cogi ad factum"13.

${ }^{11}$ Este proceso de reivindicación del derecho español había comenzado un poco antes, en las últimas décadas del siglo XVIII. En esta línea, suele destacarse la importancia que tuvo la publicación de la obra de De Asso, Ignaci - De MAnuel, Miguel, Las instituciones del derecho civil de Castilla, de 1771; así como la impresión del Fuero viejo de Castilla y del "Ordenamiento de Alcalá", todos ellos, "códigos castellanos casi enteramente desconocidos antes, y cuya lectura suministra grandes luces para la historia del derecho español' [SEMPERE, Historia, cit. (n. 1), p. 384; y véase también en este sentido, De Castro y Bravo, Derecho civil, cit. n. 1), I, pp. 133-135]. Fernández de Buján lo describe en estos términos: “en los siglos XVIII y XIX hay una prevalencia del derecho nacional que, en ocasiones, se contrapone al Derecho Romano" [FERNÁNDEZ DE Buján, Antonio, Ciencia jurídica europea y Derecho comunitario: "ius romanun”, "ius commune”, “Common Law”, "Civil Law”, en Revista General de Derecho Romano, 10 (2008), p. 433].

${ }^{12}$ Véanse las notas 2 y 3.

${ }^{13}$ La formulación del aforismo, en estos términos, suele atribuirse al jurista saboyardo Antonius Faber [o Antoine Favre (1557-1624)], quien simplemente recogió un principio que, en ese momento, ya había cristalizado en el pensamiento jurídico europeo, y que puede 
De hecho, este aforismo es referido expresamente por algunos autores españoles del siglo XIX, como fundamento de esta posición ${ }^{14}$. Es razonable suponer que, para esos autores, el derecho español vigente no modificaba el principio del nemo potest, pues, al tratar este punto, no hacen ninguna advertencia sobre la existencia de alguna diferencia entre el derecho romano y el derecho nacional, lo que es habitual en estos textos, debido a su carácter comparativo. A modo de ejemplo, considérense las palabras de Gómez de la Serna, en su Curso histórico exegético del derecho romano comparado con el español, quien afirma, a propósito de las estipulaciones, que: "las obligaciones pueden consistir no solo en dar, sino también en hacer, si bien estas últimas en el caso de inejecución por parte del promitente se convierten en otras de daños y perjuicios"15. Y más adelante, en la misma obra, al tratar el pago, afirma "no puede pagarse una cosa por otra, ni prestarse un hecho por otro, sin que consienta en ello el acreedor [...] hay, sin embargo, algunos casos en los que la necesidad justifica el que se pague diversa cosa de aquella que se debe [...] [como sucede] en las obligaciones de hacer, las que en caso de no prestarse [por] el obligado a su cumplimiento, se resuelven en obligaciones de dar" ${ }^{16}$, obligación que consiste en una cantidad equivalente del servicio que esperaba recibir ${ }^{17}$.

Es posible hallar, sin embargo, algunas referencias a ciertos pasajes del Digesto en apoyo de esta posición; aunque ello es francamente excepcional. Un ejemplo de ello se encuentra en la obra de J.A Elías y E. De Ferrater, en su Manual del derecho civil vigente en Cataluña, de 1864. Estos autores, en relación con el derecho vigente en Cataluña, afirman que "toda obligación de hacer o dejar de hacer queda reducida en caso de incumplimiento a la de prestar el obligado los daños y perjuicios que por esta razón sufra el acreedor", y tras ello, recogen, entre paréntesis, una serie de referencias de texto (aunque sin reproducirlas ni explicarlas), entre ellas, la siguiente: "L. 72 y 112 \& D. De verb. oblig. L. 24 D. de Cond. et dem."18.

rastrearse, con bastante claridad, hasta Bartolo de Sassoferrato. Sobre ello, sin embargo, no es posible ahondar en este lugar.

${ }^{14}$ Así, por ejemplo, Verlanga Huerta (véase la nota 4) y Escriche (véase la nota 5).

${ }^{15}$ Gómez de la Serna, Pedro, Curso histórico exegético del derecho romano comparado con el español (1. a ed., Madrid, Imprenta de la Compañía de Impresores y libreros del Reino, 1850), II, p. 178; a propósito de las estipulaciones.

${ }^{16}$ Ibíd., p. 364.

${ }^{17} \mathrm{El}$ autor no específica, en esta parte de su libro, a qué obligación de dar se refiere, sino que se remite, en nota al pie, a otra parte de su libro en la que expresa que "para evitar la violencia personal que sería consiguiente si se compeliera a alguno a hacer o a no hacer lo que no quiere, se ha establecido que no pueda el actor pedir la prestación del hecho, sino solo que se le dé una cantidad equivalente al servicio que esperaba recibir, es decir, que la obligación de hacer o no hacer se convierte en una de dar, habiendo en este caso, por el ministerio de la ley una novación" (ibíd., pp. 190-191). En ningún momento el autor contempla referencia alguna al hecho de que ello esté modificado por el Derecho español vigente.

${ }^{18}$ Elías, José Antoni - De Ferrater, Esteban, Manual del derecho civil vigente en Cataluña (2a edición, Barcelona, Imprenta de Ramírez, 1864), p. 403. Las citas de estos autores a "D. De verb. oblig." se refieren a Dig. 45,1, segunda parte (“de verborum obligationibus"). El primero de los pasajes citados (D. 45,1,72) sirve de argumento a la posición de Elías - De Ferrater, pues en dicho pasaje se recoge la opinión de Ulpiano, quien sostiene que si se ha estipulado "hacer alguna cosa", y no se cumple, debe condenarse al pago de una suma de dinero, citando 
Por último, en apoyo de esta posición, es también posible hallar algunas referencias genéricas a la doctrina de los antiguos "intérpretes", o a los juristas medievales. Escriche, por ejemplo, en su Diccionario razonado, tras afirmar que "toda obligación de hacer o no hacer se reduce a la satisfacción de daños y perjuicios, en caso que el deudor no quiera ejecutarla", agrega que "[lo dicho] es conforme a lo que opinan los intérpretes [...] fundados más bien en las leyes romanas que en las nuestras"; referencia genérica que, en la tercera edición, se complementa con una referencia específica al jurista Antonio Gómez ${ }^{19}$.

Lo que se ha dicho hasta ahora no quiere decir, sin embargo, que para la doctrina civil española del siglo XIX fuera un principio indiscutible que, según el derecho romano, el deudor de una obligación de hacer no pudiese ser compelido al cumplimiento específico ${ }^{20}$; ni permite concluir que el significado y alcance del

la doctrina de Celso. Que los otros dos textos citados por estos autores puedan servir para apoyar su posición resulta más dudoso. D. 45,1,112 es un pasaje que trata sobre el alcance de una obligación alternativa ("Si alguno hubiera estipulado a Estico o a Pánfilo, al que de los dos él mismo quisiera, pedirá el que hubiere elegido, y sólo éste estará comprendido en la obligación; mas preguntándose si podrá cambiar de voluntad y pasar a pedir el otro se habrá de atendera las palabras de la estipulación, si fueran tales: "el que yo hubiere querido", o 'el que yo quiera'; porque si fueron estas: 'el que yo hubiere querido', una vez que hubiere elegido, no podrá cambiar de voluntad; pero si tuviera otro alcance el lenguaje de aquél, y fuera este: 'el que yo quiera' tendrá facultad para cambiar hasta que manifieste su resolución”) y no parece posible desprender de él nada en relación con el derecho al cumplimiento, o no, tratándose de una obligación de hacer. Por su parte, la referencia a la "L. 24 D. de cond. et dem." (cita que debe entenderse referida a D. 35,1,24) tampoco parece servir para apoyar la posición de estos autores, porque este pasaje trata de las asignaciones testamentarias condicionales, y no se refiere al incumplimiento de una obligación de hacer ("Está admitido en derecho civil, que siempre que por aquel, a quien le interesa que se cumpla la condición, se hace que no se cumpla, se considere lo mismo que si se hubiese cumplido la condición; lo que extendieron los más también a los legados, y a las instituciones de herederos. Con cuyos ejemplos opinaron con razón algunos, que también se incurría en las estipulaciones, cuando por el que prometía se hubiese hecho de modo que el que estipulaba no cumpliese la condición"). La traducción de estos, y todos los textos del Digesto, de García del Corral, Ildefonso, Cuerpo del derecho civil romano (Barcelona, Jaime Molina, editor, 1889).

${ }^{19}$ En las dos primeras ediciones del Diccionario razonado, en el respectivo pasaje (entrada o voz: "obligación de hacer o no hacer") no hay cita a estos "intérpretes", pero en la $3^{a}$ edición, del año 1847 , se agrega a continuación de esta afirmación reproducida en el cuerpo del texto, la siguiente referencia: "Gomez Var., lin. 2, cap. 10" (p. 648). Sin ninguna duda, esta referencia de Escriche debe entenderse hecha a Antonio Gómez, jurista del siglo XVI y a su obra Variarum resolutionum iuris ciuilis communis et regii commentaria, de 1552. El pasaje de Gómez, al que se refiere Escriche, dice: "La promesa de hecho propio es válida y de ella nace acción eficaz, sucediendo después de la mora la obligación al interés, de suerte que este o el hecho se puede pedir, o uno y otro alternativamente que es el mejor modo, y perteneciendo la elección al deudor en tales términos que aunque el acreedor pida el hecho y el Juez lo condene en él, satisfaciendo el interés queda libre de la obligación, porque ninguno puede ser compelido precisamente al hecho, en atención a que de otro modo se ofendería la libertad y se induciría cierta especie de servidumbre; bien que en algunos casos puede ser apremiado con precisión al hecho" [el texto aquí reproducido, originalmente en latín, ha sido tomado de la versión en español de GuTiérrez, Joseph Marco, Compendio de las varias resoluciones de Antonio Gómez (Madrid, Imprenta de Benito Cano, 1789), parte 2a , capítulo $10^{\circ}$, párrafo 23 , p. 94].

${ }^{20}$ En este sentido, Marti, por ejemplo, se pregunta "si el hecho es posible aún [tras el incumplimiento] jpodrá precisarse al obligado a que lo verifique, o bien, a pesar de la circunstancia 
aforismo "nemo potest praecise cogi ad factum" fuera un punto pacífico entre los autores ${ }^{21}$.

b) Los argumentos de la posición que admite la posibilidad de compeler al deudor al cumplimiento específico. Por su parte, quienes sostienen que sí es posible compeler al deudor al cumplimiento específico de la obligación de hacer se fundan en el principio "pacta sunt servanda"22; pero, sobre todo, encuentran apoyo en ciertas leyes de las Partidas -texto que, como es sabido, es la principal fuente del derecho civil español hasta la entrada en vigor del Código Civil en materia de obligaciones y contratos-. En concreto, las siguientes leyes: Part. V,11,13; V,11,35; V,14,3 y III,27,523.

de la posibilidad, no escistirá [sic] otra obligación que la de reparo de perjuicios?". Y, tras apuntar dos argumentos de texto (de derecho romano) contradictorios, afirma que "faltan los datos indispensables para una solución satisfactoria" [MARTI, Ramón, Tratado elemental del Derecho civil romano y español (Barcelona, Imprenta de Joaquín Verdaguer, 1838), II, pp. 115-116]. Mientras que Benito Gutiérrez, por ejemplo, señala con claridad que "los romanos, esclavos de la obligación, exigían el cumplimiento de la manera o forma que habia sido contraida", aunque esta afirmación contradice la idea de que en el derecho romano primaba la regla de la pecuniaria condemnatio; pero Marti hace tal afirmación sin ofrecer ningún fundamento [cfr. GuTiérReZ FERnÁndez, Códigos, cit. (n. 9), IV, p. 55].

${ }^{21}$ En este sentido, resulta interesante recoger las palabras de Hernández de la Rúa: " $L a$ obligación es el vinculo legal que obliga a los hombres a dar o a hacer aquello en que se han convenido [...] se nos puede apremiar al cumplimiento [...] tanto los hechos, como las cosas, pueden ser materia de obligaciones y [...] cualquiera sea de ellas la que se prometa, hay obligación de cumplirla, no obstante el principio nemo ad factum tenetur, que ha dado lugar a infinidad de opiniones entre los intérpretes; porque si bien es cierto, que este es un principio legal, no lo es menos, que igual origen tiene el que parece contrario, quis ad factum tenetur. Cada uno de estos axiomas legales es aplicable bajo su verdadero sentido. El primero quiere decir, que cuando la obligación consiste en hacer, como sea imposible que se obligue a la materialidad de un hecho, no se podrán usar medios de violencia fisica para hacerlas cumplir; y el segundo, que no por tanto se libra de la responsabilidad moral $y$ civil, a que le condena su promesa, sino que judicialmente se deberán buscar medios más análogos, para hacer efectiva la obligación" [HERNÁNDEZ DE LA RÚA, Vicente, Lecciones de Derecho español (Madrid, Imprenta de don Salvador Albert, 1838), II, pp. 131-132].

${ }^{22}$ En este sentido, Escriche sostiene que, debido a que según la "ley 1, tit. 1, lib 10 Nov. Rec. queda obligado cualquiera, de cualquier modo que quiso obligarse, son de parecer algunos que quien promete hacer alguna cosa, debe hacerla en todo caso, y ser apremiado a ello, siempre que el hecho sea posible y convenga al acreedor o estipulante" [ESCRICHE, Diccionario razonado, cit. (n. 5), s.v. "obligación de hacer o no hacer"]. No está de más recordar que esta ley de la Novísima Recopilación recoge el principio del consensualismo, adoptado originalmente en el derecho español en el "Ordenamiento de Alcalá".

${ }^{23}$ En esta enunciación de leyes de las Partidas, dejaremos de lado a la Part. V,6,5, que es en la que apoya Sala su tesis de que puede compelerse al deudor al cumplimiento específico [SALA, Ilustración, cit. (n. 6), p. 237]. Ello por dos motivos. Por un lado, porque esa ley, a diferencia de las otras leyes que antes se han enumerado, no aparece citada por otros autores, sino sólo por Sala. Y además, porque, en el mejor de los casos, esa ley únicamente permite afirmar que el acreedor tiene derecho a compeler al deudor al cumplimiento de una prestación de hacer cuando el contrato sea un contrato "innominado" y no sirve, por tanto, para justificar ese derecho a compeler al deudor al cumplimiento tratándose de servicios remunerados en dinero, los cuales, para las Partidas y para el derecho civil del siglo XIX, quedan comprendidos en el contrato de arrendamiento. Y decimos "en el mejor de los casos", porque Sala generaliza una solución que, según se desprende de la Part. V,6,5, es sólo para algunos supuestos de contratos innominados, 
De Part. V,11,13, suele citarse la línea "develo apremiar el juez que lo cumpla"; y de Part. V,11,35, suele citarse la línea: "tenudo es de pechar la pena, o de dar o de fazer lo que prometio, qual mas quisiere aquel que rescibio la promission" 24 .

Sobre estas dos leyes, lo primero que hay que apuntar es que ambas se encuentran dentro de un mismo título, que trata de las estipulaciones o promissiones, materia que, como es sabido, ya no tenía aplicación en el siglo XIX. No obstante, no debe extrañar que sea precisamente entre estas leyes que se busque el fundamento jurídico de esta posición, porque es a partir de esta regulación -la de las estipulaciones que se contiene en las Partidas- que los juristas castellanos construyeron lo que hoy puede denominarse teoría general de las obligaciones y del contrato ${ }^{25}$.

Pues bien, sentado lo anterior, hay que indicar que no parece que ninguna de dichas dos leyes reconozca expresamente el derecho del acreedor a obtener el cumplimiento específico de la obligación de hacer incumplida. En efecto, la primera de esas leyes (Part. V,11,13) efectivamente dice que el juez debe apremiar al deudor ("develo apremiar [...] que lo cumpla"), pero del texto se desprende que

no para todos ellos. En efecto, como se desprende de la lectura de Part. V,6,5, la posibilidad de exigir el cumplimiento específico sólo se predica respecto de los contratos "hago para que des" (en donde la obligación incumplida que puede exigirse in natura es la de entregar la cosa, no la de hacer) y en los de "hago para que hagas". Según esta misma ley, si el contrato es de "doy para que hagas", y el obligado a hacer luego no cumple, quien dio la cosa (el acreedor) no tiene una opción entre el cumplimiento específico y la indemnización (que es lo que plantea Sala), sino entre la restitución de lo dado y la indemnización del daño. Lo dicho queda todavía más claro si se considera que, esta ley de las Partidas se basa, como el propio Sala apunta, en la "L. 5 de praescrip. verb", o sea, en D. 19,5,5. En este pasaje del Digesto es claro que si se ha dado para que se haga, y lo dado es dinero, el contrato es locación, y si es otra cosa, no será locación, pero "nacerá la acción civil o por lo que me importa, o la condición para repetirla" ["sed nascetur vel civilis actio in hos, quod mea interest, vel ad repetendum condictio" (D. 19, 5, 5, 2)]. La generalización de Sala en este punto, puede tomarse como una muestra de la falta de exactitud que algunos autores del siglo XIX acusaban en el texto de Sala: "en [la] Ilustración del derecho real de España se encuentran defectos tan sustanciales, que a pesar de lo raro y necesario de la obra, $y$ del prestigio que haya podido ganarle el haber sido adoptada por texto en las universidades, tiene en contra suya el voto general de los maestros y de los estudiantes de derecho. Muchas de las citas que hace a nuestras leyes están erradas" [ÁLVAREZ, José María, Instituciones de derecho real de España (Madrid, Imprenta de Repullés, 1829), p. ii]. Y, en el mismo sentido: "el Sala hizo un trabajo muy apreciable [...] no tiene, sin embargo, en toda su obra, una sola definición que sea exacta, un solo principio de que sepa deducir después consecuencias naturales, ni una sola esplicación [sic] que pueda decirse metódica y ordenada" [ÁLVAREZ MarTíneZ, Cirilo, Instituciones de derecho civil (Valladolid, Imprenta de Julián Pastor, 1840), p. vi].

${ }^{24}$ Citan estas leyes, en apoyo de esta posición, entre otros: Elías - De ferRater, Manual del derecho civil, cit. (n. 18), p. 608; FALCón, Exposición doctrinal, cit. (n. 10), p. 446; GARCía GoYenA, Concordancias, cit. (n. 7) III, pp. 46-47; GutiérRez Fernández, Códigos, cit. (n. 9), IV, p. 55.

${ }^{25}$ Sobre el punto, véase GuZMÁn Brito, A., La promesa obligacional en las partidas como sede de la doctrina general de las obligaciones, en Revista Chilena de Derecho, 34 (Santiago, 2007) 3, pp. 395-404. El autor, al final de su estudio, expresa: "la doctrina de la promisión, que en sí misma era nada más que pura teoría, cumplía en el Derecho común castellano [...] el papel de servir de sede a lo que hoy llamamos teoría general de las obligaciones, en el interior de un sistema jurídico, como era el común, que carecía de la noción sistemática moderna de las 'partes generales'. Tal es, si no me equivoco, la razón por la cual la jurisprudencia del derecho común conservó su estudio y análisis pese a su impracticabilidad formal” (p. 402). 
esta ley tiene por objeto determinar a partir de qué momento y en qué lugar puede exigirse la obligación, cuando en ella no se ha fijado plazo o lugar para el cumplimiento. En efecto, Part. V,11,13 -demasiado extensa para reproducirla completa aquí- trata sobre "fasta quanto tiempo deue ser complida la promission". En ella, se dice que, en caso que se hubiera prometido dar o hacer alguna cosa, sin fijar una fecha, el juez, si considera que ya ha transcurrido un plazo razonable "develo apremiar a que la cumpla"; y también que, si no se ha fijado un lugar para el cumplimiento, "develo apremiar el juez del logar que lo cumpla alli". Del texto de esta ley -y ya para algunos autores del siglo XIX era claro- se desprende que las Partidas no tratan aquí directamente sobre el cumplimiento específico, sino que se limitan a regular algunos aspectos sobre el plazo en que debe cumplirse la obligación ${ }^{26}$. En cuanto a Part. V,11,35, ésta parece ofrecer todavía menos base que Part. V,11,13 para justificar esta posición favorable al cumplimiento específico, pues aquella se refiere al carácter acumulativo o no de la pena convencional respecto de la obligación principal, y no al derecho al cumplimiento específico ${ }^{27}$.

Otra ley en la que se apoya la posición favorable al cumplimiento específico es Part. V,14,3, a propósito de las pagas. De ella suele citarse el siguiente fragmento: "Pagamiento de las debdas deve ser fecho a aquellos que las han de recebir, $e$

${ }^{26}$ En este sentido, por ejemplo, MarTi, Tratado elemental, cit. (n. 20), p. 117. Así, pues, esta ley no se refiere al cumplimiento o incumplimiento de la obligación de hacer, sino que se refiere a las obligaciones a plazo, pudiendo considerarse como un antecedente del art. $1128 \mathrm{CC}$ español:"Si la obligación no señalare plazo, pero de su naturaleza y circunstancias se dedujere que ha querido concederse al deudor, los Tribunales fijarán la duración de aquél./ También fijarán los Tribunales la duración del plazo cuando éste haya quedado a voluntad del deudor"; así lo recoge, por ejemplo, ScaEvola, Quintus Mucius, Código civil comentado y concordado extensamente (Madrid, Imprenta de Ricardo Rojas, 1893-1915), XIX, p. 682 (en el comentario al artículo 1128 CC). Por otro lado, modernamente se ha sugerido que, aun cuando en esta ley se utiliza la expresión "apremiar", debe entenderse que con ello simplemente se está diciendo que el juez debe fijarle un plazo para que cumpla, no que esté autorizado a emplear medidas directas o indirectas de apremio, como se explica más adelante.

${ }^{27} \mathrm{Y}$ es que, además de lo que se desprende del propio texto de la Part. V,11,35, las explicaciones que lo acompañan (ya en la glosa de Gregorio López) muestran claramente que esta ley no tiene relación con el problema de la ejecución específica de las obligaciones de hacer, sino que tiene relación con el problema de determinar si, habiéndose pactado una pena, se debe la obligación principal o sólo la pena. En este sentido, la glosa que acompaña este texto señala que la opinión mayoritaria entre los glosadores era que sólo se debía la pena, por entenderse que había novación; pero que en las Partidas, esta ley adopta una solución diferente, pues establece que el acreedor puede elegir entre la obligación principal y la pena. La discusión, sin embargo, parece subsistir en los siglos XVIII y XIX. Que no pueden acumularse obligación principal y pena aparece ya claro para DE ASSO - DE MANUEL: "la [pena] convencional debe satisfacerse si no se cumple la promesa a tiempo, y esta satisfacción libera de la obligación" [Instituciones, cit. (n. 11), p. 172 (utilizo aquí la 5a ed., de 1792)]; que es el acreedor quien elige entre la obligación principal y la pena, se observa con claridad en Álvarez: "pero en estos casos queda al arbitrio del acreedor, $o$ exigir la pena, o el cumplimiento de la promesa" [Instituciones de derecho real, cit. (n. 23), II, p. 46]. Siguiendo estos precedentes, el artículo 245 C.Com 1829 establecía la no acumulación entre la pena y el cumplimiento, contemplando expresamente el derecho del acreedor a el e gir: "Cuando en el contrato de comercio se haya fijado pena de indemnización contra el que no lo cumpliere, puede la parte perjudicada exigir o bien el cumplimiento del contrato por medios de derecho, o bien la pena prescrita; pero usando de una de estas dos acciones, queda extinguida la otra". 
devese fazer de tales cosas, como fueron puestos, et prometidas en el pleyto" 28 . Ahora bien, Part. V,14,3 no dice expresamente que sea posible compeler al deudor al cumplimiento de una obligación de hacer. En realidad, de lo que trata esta ley es de lo que hoy se denomina la "identidad" del pago. Y, en este sentido, esta ley establece, que no siendo posible para el deudor cumplir de la forma establecida, debe cumplir del mejor modo posible, según sea el criterio del juez, y además debe, por ello, indemnizar al acreedor ${ }^{29}$. La doctrina del siglo XIX desprende de este texto dos cosas: la primera, que "el pago debe hacerse en las mismas cosas que se deben" 30 ; la segunda, y más importante en lo que aquí interesa, es que siendo posible el hecho prometido, "el deudor no quedará libre pagando el id quod interest"; de lo que se desprende, a su vez, que siendo posible la obligación, se puede compeler al deudor a su cumplimiento, y que el deudor no puede elegir entre el cumplimiento específico y la indemnización de daños ${ }^{31}$.

${ }^{28}$ El texto es el siguiente: "Pagamiento de las debdas deve ser fecho a aquellos que las han de recebir, e devese fazer de tales cosas, como fueron puestos, et prometidas en el pleyto, cuando lo fizieron, e non de otras, si non quisiere a quien fazen la paga, pero si acaesciesse, que el debdor non pudiesse pagar aquellas cosas que prometiera, bien puede darle entrega de otras, a bien vista del Judgador. Otrozi dezimos que si ouiesse fecho pleyto de fazer alguna cosa, e non lo pudiese fazer en la manera que avia prometido, que debe complir de otra guisa el pleyto, según su alvedrio del Judgador del lugar. E debe pecharle el daño, o el menoscabo que le vino por razon que non fizo aquella cosa, assi como prometio [...]".

${ }^{29} \mathrm{Y}$ precisamente, es en ese sentido que la Part. V,14,3 es citada por algunos autores del siglo XIX. Fernández de la Hoz, por ejemplo, la utiliza como base para afirmar, a propósito del pago de las obligaciones, que "para que la paga surta el efecto de estinguir [sic] la obligación debe ser total y exacta, lo cual se verifica pagando toda la cantidad adeudada y cumpliendo al hacer el pago todos los requisitos espresados [sic] en el contrato y los que la ley y la costumbre tienen establecidos, pues no lo haciendo asi no está obligado el acreedor á recibirla" [FERNANDEZ DE LA HOZ, José María, Código civil redactado con arreglo a la legislación vigente (Madrid, Imprenta de D. Eusebio Aguado, 1843), p. 177]. Y Sánchez de Molina cita esta ley para aplicarla específicamente a la obligación de hacer, señalando que "si la obligación consistiese en un hecho y el deudor no pudiera prestarle del modo convenido debe cumplir del mejor modo posible, según albedrio del juzgador, indemnizando al acreedor de los daños y perjuicios que le ocasione la falta de cumplimiento en la forma estipulada" [SÁNCHEZ DE Molina BlANCO, J., El derecho civil español, en forma de código (Madrid, Imprenta de D. J. L Viscaín - D. Manuel Minuesa, 1871), p. 274].

${ }^{30}$ Álvarez Martínez, Instituciones, cit. (n. 23), p. 316.

${ }^{31}$ Esa explicación se puede hallar ya en la glosa de Gregorio López (1496-1560) a la Part. $\mathrm{V}, 14,3$, señalándose, además, que esa solución es contraria a la mayoritariamente admitida por los juristas medievales y que, además, la solución del derecho español encuentra apoyo en la legislación canónica. Originalmente, en la glosa 4 a Part. V,14,3: "Innuit, quod si posset facere, cogitu praecise facere, \& non liberatur solvendo interesse [...] non procedet communis opinio Bart. $\circlearrowleft$ aliorum dicentium quod in obligationibus facti regulariter succedat obligatio ad interesse [...] corrboratur, quia de aequitate canonica obligatus ad factum si adimplere potest praecise, potest compelli [texto tomado de Las siete Partidas del Sabio Rey don Alfonso el sabio, glossadas por el Sr. D. Gregorio López (con indicación en el título de que se reimprime la glossa del Sr. López por el tenor de la edición de Salamanca del año 1555), por el Dr. D. José Berni y Catalá (Valencia, Imprenta de Benito Monfort, 1767]. En la versión de Sanponts y Barba y otros esta glosa de López se recoge, traducida al español, en la glosa 11 a la Part. V,14,3: "luego, si se puede cumplir lo mismo que prometió, no quedará libre pagando el id quod interest [...] por consiguiente por nuestro derecho no será admisible la general opinión de Bart y otros, a saber, que se convierte por lo regular 
Por último, la posición favorable a la posibilidad de compeler al deudor al cumplimiento de la obligación de hacer, en los términos pactados se apoya también en Part. III,27,5. Esta ley se encuentra a propósito del cumplimiento de las sentencias. Por tratarse de una norma de carácter procesal, y no de derecho sustantivo, corresponde tratarla en el siguiente apartado.

c) La ausencia de jurisprudencia en pro de alguna solución. Expuestos los argumentos de la doctrina española del siglo XIX sobre la base del derecho sustantivo, tanto a favor como en contra de la posibilidad de exigir al deudor el cumplimiento específico de la obligación de hacer, conviene destacar que ninguna de esas dos posiciones doctrinales se apoyan o son contrastadas con la jurisprudencia. En efecto, de todos los autores a los que se ha hecho referencia en las páginas anteriores, los únicos que citan jurisprudencia del Tribunal Supremo español son Elías y De Ferrater, quienes, tras afirmar que la obligación de hacer "se convierte en una de indemnizar daños", apuntan: "STS de 18 de marzo de 1863", sin mayor explicación. Revisada la Colección legislativa de sentencias del Tribunal Supremo del año 1863, la única sentencia ahí contenida, de dicha fecha, lo fue en casación, dictada por la Sala de Indias ${ }^{32}$. Y si bien en ella se cita efectivamente las mismas leyes de las Partidas a las que se ha hecho referencia antes (Part. V,11,13 y V,11,35), no parece posible afirmar que, en este caso, el Tribunal Supremo niegue el derecho del acreedor a insistir en el cumplimiento específico, porque en el caso, el demandante-acreedor no solicitó el cumplimiento específico (cumplimiento que, por lo demás, era materialmente posible) sino que lo que solicitó fue una indemnización de daños ${ }^{33}$.

en la de daños e intereses la obligación de hacer [...] en apoyo de ella [de la solución adoptada por las Partidas] viene la equidad canónica, al tenor de la cual, el que se obligó puede ser compelido a verificar lo mismo que prometió, mientras no haya venido a hacer imposible" [SANPONTS Y BARBA, Ignacio - Marti De Eixala, Ramón - Ferrer y Subirana, José, Las siete Partidas (Barcelona, Imprenta de Antonio Bergnes, 1843)].

${ }^{32}$ Ministerio de Gracia y Justicia, Colección Legislativa. Sentencias del Tribunal Supremo, Edición oficial (Madrid, 1983) n. 63, p. 215.

${ }^{33} \mathrm{El}$ caso fue el siguiente: En junio de 1856, la junta de accionistas de una sociedad (A) decidió nombrar a B como director, quien aceptó el cargo, en el caso que el Rey admitiera su renuncia a ciertos cargos, renuncia que B presentó a los pocos días. No obstante, la renuncia a estos cargos fue aceptada en septiembre de 1858, y se le comunicó de ello en noviembre de 1858. (B) comunica a (A) que entrará en el cargo de director a partir del 1 de enero del año siguiente. Considerando el tiempo transcurrido (algo más de dos años), se celebró una nueva junta de accionistas, que acordó no otorgar el cargo a (B). Pero, (B) no demandó que se le permitiera ocupar el cargo, sino que pidió una indemnización por los "daños y perjuicios que se causaron en sus intereses, reputación y crédito" y por "el sueldo perdido". La compañía (A) se defendió señalando que el cargo no tenía un plazo predeterminado, sino que era cargo de confianza y que, por tanto, tenía facultad para nombrar y destituir a los directores en cualquier momento. En primera instancia se acogió la demanda; pero en segunda se revocó la sentencia. De ahí que B planteó recurso de casación, señalando como infringidas, entre otras, Part. V,11,13 y Part. V,11,11. El Tribunal Supremo resolvió a su favor, sentando esta doctrina: "Que según los preceptos establecidos en las leyes 11 y 35 del título 11 de la Partida 5. a, y en la 1.a tít. 10 de la Novísima recopilación, pareciendo que alguno se quiso obligar a otro por promisión o por algún contrato o en otra manera, está obligado a cumplir lo que prometió o a pagar, si no lo verificare, los daños y perjuicios ocasionados a aquel a cuyo favor se obligón" [considerando primero, que no están 


\section{LA EXISTENCIA Y LA NATURALEZA}

DE LAS VÍAS PROCESALES DE APREMIO CONTRA DEL DEUDOR

Junto a los anteriores argumentos de derecho sustantivo, puede afirmarse que el otro factor que incide en la distinta percepción de los autores del siglo XIX sobre la posibilidad, o no, de obtener del deudor el cumplimiento específico de la obligación de hacer, es la existencia y la naturaleza de vías procesales de apremio contra aquél, en la fase procesal de ejecución. En este sentido, como es sabido, el siglo XIX estuvo marcado por una sucesión de regulaciones procesales. En la primera mitad del siglo, la principal regulación del procedimiento ejecutivo se encuentra contenido en las Partidas. En la segunda parte del siglo XIX ve la luz la primera Ley de enjuiciamiento civil, del año 1855 , la que fue reemplazada, casi tres décadas más tarde, por la Ley de enjuiciamiento civil de 1881.

a) La primera mitad del siglo XIX: las Partidas. Siendo las Partidas la principal regulación del procedimiento ejecutivo hasta la entrada en vigor de la Ley de enjuiciamiento civil de 1855, no es de extrañar que, entre los autores que afirman que es posible compeler al deudor al cumplimiento se cite, en apoyo, Part. III,27, $5^{34}$. Esta ley-que está dentro del título que trata de Como los Juyzios, que son valedereos, deven ser cumplidos, e quien los puede cumplir- señala: "[...] si la sentencia fuesse contra el demandado en razon de alguna cosa que deviesse fazer, develo apremiar que la faga assi como fue puesto, o lo prometio".

De esta ley se desprende con claridad que es posible obtener una condena "a hacer algo", y que el deudor puede, en tal caso, ser "apremiado" al cumplimiento de dicha condena. No obstante, hay que tener presente al menos dos aspectos que resultan importantes. Primero, que no se especifican cuáles serían los medios por los que se puede compeler al deudor en este caso (a diferencia de lo que ocurre cuando la sentencia condena al pago de una suma de dinero o a entregar ciertas cosas, caso en el cual se dice expresamente que pueden tomarse los bienes por la fuerza $)^{35}$. Segundo, que se ha sugerido que por "apremiar" debe entenderse aquí "que se dejaba a la discreción del juez el señalamiento del plazo oportuno para que

numerados]. Como se ve, en este caso no hay ningún pronunciamiento sobre el derecho del acreedor a obtener el cumplimiento específico; el Tribunal Supremo sólo se afirma el derecho del acreedor de ser resarcido en caso de incumplimiento [Colección Legislativa. Sentencias, cit. (n. 32), pp. 192-195].

${ }^{34}$ Así, Gutiérrez Fernández, quien además agrega que, según la Part. V,6,5, "para que la obligación de hacer no cumplida se convierta en la de abonar daños y perjuicios, es necesario presuponer engaño" [GuTiérRez Fernández, Códigos, cit. (n. 9), IV, p. 56]. Según el autor, el medio propuesto en el Proyecto de Código [el autor se refiere aquí al artículo 1088 Pyto. CC. 1851, transcrito en la nota 3] se considera como el “mejor en la práctica" (ibíd., p. 59).

${ }^{35}$ Para el caso en que la condena consista en la entrega de un cuerpo cierto, Part. III,27,3, dentro del mismo título, establece: "entonce deven cumplir el juyzio en aquella cosa misma, de qual natura quier que sea"; y para los casos de condenas dinerarias, el orden de los bienes en los que se debe cumplir la condena (primero, deben tomarse los muebles, luego, y sólo a falta de éstos, los inmuebles). La ley $2^{a}$ de ese mismo título señala que estas cosas (bienes que deben entregarse o venderse), si no son entregadas voluntariamente, lo pueden ser por la fuerza (con "omes armados"). 
el ejecutado cumpliera, bajo apercibimiento de realización forzosa de los bienes", y, por tanto, "apremiar" no implicaría la posibilidad del juez de emplear ciertas medidas de apremio contra el deudor, como la prisión o la toma de ciertos bienes ${ }^{36}$.

Para saber si en este período -la primera mitad del siglo XIX- se admitía o no el uso de ciertas vías de apremio, es conveniente, pues, recurrir a la doctrina procesal. Si tomamos como referencia el principal tratado de derecho procesal existente a comienzos del siglo XIX -la Curia Philipica de De Hevia Bolaños ${ }^{37}$ parece posible afirmar que el acreedor no sólo podía, en ciertos casos, obtener una sentencia que condenase al deudor a ejecutar la prestación de hacer ${ }^{38}$; sino que además era posible despachar el mandamiento de ejecución ordenando hacer algo "bajo apercibimiento de" emplear ciertas vías de apremio determinadas, a saber: prisión, secuestro y toma de bienes ${ }^{39}$.

${ }^{36}$ Es lo que sostiene Carballo Piñeiro, quien afirma, a continuación, que la ejecución "se ceñia a la ejecución forzosa de los bienes" [CARBAllo PiñeIro L., Aspectos históricos de la ejecución de condenas no dinerarias (2a Parte): del periodo visigodo a nuestros días, en Dereito, 12 (Santiago de Compostela, 2003) 1, p. 18]. En este punto, hay que tener presente, que en la época de las Partidas se admitían como medios de presión para obtener el cumplimiento de las obligaciones, tanto el arresto del deudor como la toma de ciertos bienes, aunque se trata de medidas que se aplicaban de forma limitada. En relación con la prisión, la misma autora explica que en las Partidas queda sólo como un medio subsidiario, "una prisión-servidumbre" en caso de insolvencia o de que los bienes cedidos no alcanzasen a satisfacer los créditos [ibíd., p. 20]. En relación con la segunda de estas vías (toma de cierto bienes), hay que considerar que "las prendas hechas de bienes raíces o muebles, y tomadas legitimamente, eran un medio autorizado por las leyes Góticas y observado constantemente en Castilla en lugar de prisiones, para obligar a los hombres a cumplir sus contratos y obligaciones [...] con todo [...] los legisladores [...] prohibieron rigurosamente el uso de prendar, siempre que la persona obligada diera fiador de cumplir de derecho y que el acreedor o querelloso jamás pudiera hacerlo por si mismo" [MARTínez MARINA, Ensayo histórico-crítico, cit. (n. 1), p. 151].

${ }^{37}$ Como es sabido, se trata de un texto que data de comienzos del siglo XVII (la primera edición vio la luz posiblemente en 1603), pero que fue reeditado en varias ocasiones durante los siglos XVIII y XIX. En el siglo XIX, seguía considerando un texto básico de Derecho procesal. En las citas que siguen, se utiliza: De Hevia Bolaños, La Curia Philipica. Reimpresión oficial, ordenada por el Supremo Consejo de Castilla (Madrid, 1797). Para una presentación general de esta obra y de su autor, véase Coronas, S. M., Hevia Bolaños y la Curia Philipica, en Anuario de Historia del Derecho español, 77 (Madrid) 2007, pp. 77-93. Por último, conviene tener presente que si bien la autoría de De Hevia ha sido puesta en tela de juicio a lo largo de la historia, hoy, plantea Coronas, "este debate puede darse por resuelto a favor de Hevia una vez despejadas ciertas dudas sobre su personalidad y la naturaleza de su obra" (ibíd., p. 77).

38 "El instrumento [se refiere a "título ejecutivo"] en que se promete hacer algún hecho, trae aparejada ejecución, asi en quanto á la compulsion de hacerle precisamente en los casos que ha lugar, como en cuanto a la estimación é intereses". Y sigue luego: "La obligación del hecho regularmente es alternativa de hacerle, ó pagar la estimación, ó interés, á la elección del que se prometió hacer, salvo que puede ser apremiado á hacerlo precisamente en [ciertos] [...] casos" [DE Hevia, Curia Philipica, cit. (n. 37), p. 115]. Estos casos son los siguientes: "el primero, cuando el hecho se debe hacer en Juicio para algún caso de él. El segundo, cuando por ley hay obligación de hacerle. El tercero, cuando es a favor de la República, como para usar en ella algún oficio, o arte, ó otra cosa semejante, o cuando por testamento se manda al heredero, o legatario hacerle a favor de la República. El cuarto, cuando es sobre acción Real, para el entrega de alguna cosa. El quinto, cuando se jura de hacerle [...] El sexto, cuando por instrumento ejecutivo fue prometido o hay obligación de hacerle" (ibíd., p.115).

${ }^{39}$ Vale la pena reproducir las palabras de De Hevia: "cuando se trata de algún hecho personal, 
b) La segunda mitad del siglo XIX: Leyes de enjuiciamiento civil de 1855 y de 1881 . Asumiendo que lo que se ha dicho hasta ahora refleja cuál era el estado de cosas en la primera mitad del siglo XIX, determinar si la entrada en vigor de la Ley de enjuiciamiento civil de 1855 supuso, o no, un cambio, no es fácil. Y es que, aun cuando es claro que bajo la Ley de enjuiciamiento civil de 1855 era posible que la sentencia condenase al demandado a hacer alguna cosa ${ }^{40}$, esa Ley de enjuiciamiento no contemplaba vías de apremio sobre la persona o los bienes del deudor para compelerle a cumplir con dicha condena, no, al menos, de forma expresa. En efecto, ni la prisión, ni la toma de bienes (ni otras posibles medidas de apremio, como por ejemplo, la imposición de multas) aparecen sancionadas expresamente como posibles vías para compeler al deudor a ejecutar el hecho debido. La norma rectora en esta materia era el art. 895 LEC de 1855, que únicamente señalaba: "si la sentencia contuviere condena de hacer o no hacer, se procederá a darle cumplimiento empleando los medios necesarios al efecto".

Qué es lo que implicaba esa afirmación del artículo 895 LEC. 1855, es algo que no resultaba evidente para la doctrina española de la época. Para algunos, ese artículo autorizaba al juez para utilizar cualquier medida que considerase adecuada en pos de obtener el cumplimiento [en este sentido, Manresa y Reus (1869)] ${ }^{41}$. Para otros, en cambio, se trataba de una mera declaración general, siendo necesario recurrir a lo dispuesto en los artículos inmediatamente siguientes para concretar esa declaración general [en este sentido, Hernández de la Rúa (1856) ${ }^{42}$. Hay que considerar que el artículo siguiente, el art. 896 LEC. 1855, disponía que tratándose de obligaciones de hacer, si el deudor no cumplía dentro del plazo que el juez le señalaba, la prestación "se ejecutará a su costa", o bien, si el hecho era personalísimo, "se entenderá que [el deudor] opta por el resarcimiento de perjuicios" 43.

que hay obligación precisa de hacer la persona, o depósito que se debe entregar, o restituir, ha de ser compelida a ello, por prisión, secuestro, y toma de bienes, y siendo necesario, venta y remate de ellos, hasta que lo cumpla" [De Hevia, Curia Philipica, cit. (n. 37), p. 132, a propósito del mandato de ejecución].

${ }^{40}$ Surge así del texto del artículo 896 LEC. 1855: "Si el condenado a hacer alguna cosa no cumpliere con lo que se le ordene [...]".

${ }^{41}$ Manresa y Reus consideran que, en este art. 895 LEC. 1855, esos medios "[se dejan] [...] a prudencia y criterio del Juez, el cual procurará que sean los más adecuados al efecto, evitando toda dilación, vejación y gasto que no sea de absoluta necesidad' [MANRESA Y NAVARRO, José María - Reus y GarCía, José, Ley de Enjuiciamiento Civil comentada y explicada (Madrid, Imprenta de la Revista de Legislación y Jurisprudencia, 1869), IV, p. 178]. En este mismo sentido, en la doctrina moderna, se pronuncia Carballo Piñeiro, Aspectos históricos, cit. (n. 34), p. 26.

${ }^{42}$ Hernández de la Rúa, comentando el art. 895 LEC. 1855, señala: "este precepto en fuerza de la generalidad de los términos en que está concebido nada dice ¿Qué medios son los que han de emplearse? Esto es lo que interesa saber, porque en la elección estriba la dificultad" [HERNÁNDEZ DE LA RÚA, Vicente, Comentarios a la Ley de Enjuiciamiento civil (Madrid, Imprenta del Boletín de Jurisprudencia, 1856), IV, p. 103]. Y tras ello, el autor lo que hace es analizar cuáles son los medios que pueden emplearse, que para el caso de obligaciones de hacer, entiende este autor son únicamente los que estaban contemplados en el art. 896 LEC. 1851 (véase la nota siguiente).

${ }^{43}$ Art. 896 LEC. 1855: "Si el condenado a hacer alguna cosa no cumpliere con lo que se le ordene para la ejecución de la sentencia, dentro del plazo que el Juez al efecto señale, se ejecutará a su costa; $y$ si por ser personalísimo el hecho no pudiere verificarse en esta forma, se entenderá que opta por el resarcimiento de perjuicios". Hernández de la Rúa, comentando los artículos 895 y 896 
El texto del artículo 944 LEC. 1855 parece corroborar la segunda interpretación que se hacía del artículo 895 LEC. 1855 -esto es, que el juez no estaba autorizado para emplear cualquier medida de apremio- porque aquél artículo 944 LEC. 1855 disponía que "la ejecución no puede despacharse sino por cantidad líquida" ${ }^{4}$. A ello, se suma el hecho de que, entre las reglas destinadas a regular el procedimiento de apremio, no se contemplaba ninguna referencia a la ejecución de obligaciones no dinerarias, ni se contemplaban vías indirectas de apremio ${ }^{45}$.

Es razonable sugerir que la Ley de enjuiciamiento civil de 1881 recogió la expuesta segunda interpretación del artículo 895 LEC. 1855. El artículo 923 LEC. 1881 expresaba: "si la sentencia contuviera condena de hacer, o de no hacer, $o$ de entregar alguna cosa o cantidad ilíquida se procederá a darle cumplimiento, empleando los medios necesarios al efecto", agregando, al final: "y que se expresan en los artículos que siguen”. Por su parte, el artículo 924 LEC. 1881 señalaba, tal como disponía el anterior artículo 896 LEC. 1855, que "si el condenado a hacer alguna cosa no cumpliere con lo que se le ordene para la ejecución de la sentencia dentro del plazo que el Juez al efecto le señale, se hará a su costa; y si por ser personalísimo el hecho no pudiera verificarse en esta forma, se entenderá que opta por el resarcimiento de perjuicios". Así, pues, bajo la Ley de enjuiciamiento civil de 1881, resultaba bastante claro que no era posible compeler al deudor, a través de vías directas o indirectas de apremio, al cumplimiento in natura de una obligación de hacer, y que la pretensión de cumplimiento específico se traducía, respecto del deudor, en una obligación monetaria, que podía ser, según el caso, la de asumir los costes

LEC. 1851 señala: "no podía menos la Ley de enjuiciamiento de aceptar todo aquello que está en el orden natural de las cosas. ¿Cómo habia de prescindir del principio que reconoció la jurisprudencia al declarar, ad factum nemo tenetur? ¿Cómo habia de contradecir el principio, factum infectum fieri nequit? Tuvo, pues, que respetar esas verdades, y que dictar reglas que acomodándose a ellas, supliesen lo que la parte no quería hacer, o que hecho no podía deshacerse" [HERNÁNDEZ DE LA RÚA, Comentarios, cit. (n. 42), IV, p. 102]. Manresa y Reus vinculan la primera vía, la ejecución a costa del deudor, con Part. III,27,5; y la segunda, el cumplimiento por equivalente, con Part. V,14,3 [MANResa - Reus, Ley de enjuiciamiento, cit. (n. 41), IV, p. 179].

${ }^{44}$ Esta solución estaba en sintonía con la recogida en el artículo 307 LEC. 1830: "El procedimiento ejecutivo no puede recaer sino sobre cantidad numeraria, determinada y líquida". Es más, el artículo 309 LEC. 1830 señalaba que "cuando la deuda consista en efectos de comercio, se liquidará su equivalencia en numerario por los precios del mercado de la plaza [...]", de lo que se desprende que, una vez reconocido el derecho del acreedor (en el caso, el derecho a ciertas mercaderías), la obligación del deudor se convertía, en fase de ejecución, en una obligación dineraria por el equivalente dinerario.

${ }^{45}$ De hecho, toda la regulación gira sobre la base del embargo y la venta de bienes del deudor. Es cierto que uno puede pensar en algunos supuestos que, desde cierta perspectiva, podrían ser calificables como de "cumplimiento específico" de una obligación, como ocurre, por ejemplo, con la posibilidad de obtener la restitución del bien raíz arrendado (a través del lanzamiento en un juicio de desahucio: artículos 636 ss. LEC. 1851; por incumplimiento de la obligación "contractual" de restituir la cosa arrendada), o la posibilidad de que el juez dicte un interdicto de obra nueva (artículo 738 ss. LEC. 1851; que quizás podría intentarse en caso de incumplimiento de una obligación contractual de no hacer, aunque se trata de una acción de alcance general); pero, creo que se trata de casos específicos, que más bien se fundan en la protección de la propiedad, y en todo caso, ninguno de ellos corresponde a contratos de servicios. Lo mismo puede decirse de la regulación del juicio ejecutivo en la LEC. 1830. 
de la ejecución por un tercero (prestación no personalísima) o la de indemnizar los perjuicios (prestación personalísima). Y esta fue, desde entonces, la interpretación que del sistema adoptado en la Ley de enjuiciamiento civil de 1881, hizo la doctrina española de forma constante: así, si la obligación de hacer era fungible, o no personalísima, entonces la única vía posible de ejecución era la ejecución por tercero a costa del deudor ${ }^{46}$; y si el hecho era personalísimo, entonces sólo había lugar a indemnización de perjuicios (identificándose, así, la noción de no fungibilidad con la de incoercibilidad $)^{47}$. De ahí que se afirme, por parte de la doctrina procesal moderna, que la Ley de enjuiciamiento civil de 1881 recogía la máxima "nemo potest praecise cogi ad factum" 48 .

Esta solución de la Ley de enjuiciamiento civil de 1881 es consistente con la que, algunos años más tarde, adoptó el Código Civil español en su artículo 1098, precepto que todavía sigue en vigor, y dice: "Si el obligado a hacer alguna cosa no la hiciere, se mandará ejecutar a su costa./Esto mismo se observará si la hiciere contraviniendo al tenor de la obligación. Además podrá decretarse que se deshaga lo mal hecho" ${ }^{\text {‘9 }}$. Y, además, esa regulación de la Ley de enjuiciamiento civil de 1881 (en

${ }^{46}$ Por todos, Verdera Server, Rafael, El cumplimiento forzoso de las obligaciones (Bolonia, Publicaciones del Real Colegio de España, 1995), p. 288. Es interesante notar que no era claro que dicha vía de ejecución -la de cumplimiento por tercero a costa del deudor- pudiera ser calificada como una vía de cumplimiento específico. En este sentido, el mismo autor constata que "hay quien considera que la ejecución es al mismo tiempo específica (funcionalmente) y genérica (estructuralmente). Resulta específica para el ejecutante porque recibe la prestación debida y establecida en el título, aunque sea efectuada por persona distinta del obligado. Resulta genérica, por el contrario, para el ejecutado, porque deberá pagar una cantidad (sustitutiva) de dinero" (ibíd., p. 288). En opinión de Verdera, "estos supuestos pueden encuadrarse dentro del marco de la tutela satisfactoria o específica. Se trata de la respuesta del ordenamiento jurídico a la violación de un derecho, que resulta encausada a través de un mecanismo que prescinde de la voluntad del deudor. Y sobre todo, pretende conferir al acreedor justamente la prestación debida, y no una suma equivalente a los daños que se han ocasionado" (ibíd., pp. 289-290).

${ }^{47}$ Así por ejemplo, en el Auto de la Audiencia Provincial de Barcelona (Sección 15), de 1 de febrero de 2000, se consideró que la condena que ordenaba el cumplimiento de un contrato de suministro, imponiendo al demandado la obligación de recibir y vender el combustible suministrado por el demandante en exclusiva, era de obligación de hacer personalísima, y por tanto, "infungible o incoercible (nemo praecise cogi potest ad factum)" (RJ $4 .^{\circ}$ ) y que "no puede imponerse en forma especifica” (RJ 5. ${ }^{\circ}$ [(195/2000) Ponente: Ilmo. Sr. D. J. R. Ferrandiz Gabriel. Fuente: Centro de Documentación judicial del Consejo General del Poder Judicial, www.cendoj.es [consultado el 12 de mayo de 2015)].

${ }^{48}$ En este sentido, por ejemplo, Fernández-Ballesteros López, Miguel Ángel, La ejecución forzosa y las medidas cautelares (Madrid, Irgium, 2001), p. 426 n. 44; y Moreno CATENA, Víctor, Algunos problema de la ejecución forzosa, en Anuario de la Facultad de Derecho de la Universidad Autónoma de Madrid, 5 (Madrid 2001), pp. 197-198.

${ }^{49}$ Aunque, bien puede considerarse como el antecedente más próximo de ambas regulaciones de la Ley de enjuiciamiento civil C. y del Código Civil) el artículo 1088 Pyto. CC. 1851 (transcrito en la nota 3). Conviene apuntar que la influencia del Code Civil en el Proyecto de Código Civil de 1851 es, en este punto, evidente. Aun cuando el artículo 1088 Pyto. CC. 1851 no reproducía exactamente el texto del artículo 1142 Code [que señala: "Toda obligación de hacer y de no hacer se resuelve en indemnización de daños", reflejando la máxima nemo potest praecise cogi ad factum], el criterio de solución que está a la base es el mismo. Así lo verifica García Goyena, quien, precisamente comentando el artículo 1008 Pyto. CC. 1851, pone de relieve que su 
particular, la de su artículo 924) incidirá importantemente en la forma en que la doctrina civil española tratará el derecho del acreedor al cumplimiento específico de las obligaciones de hacer durante todo el siglo $\mathrm{XX}^{50}$.

\section{CONCLUSIONES}

Del estudio de que se ha dado cuenta en este trabajo, es posible concluir que: $1^{\circ}$ La idea de que el acreedor tiene derecho al cumplimiento específico de la obligación de hacer no aparece admitida con claridad en la doctrina española del siglo XIX.

$2^{\circ}$ Aunque la posición favorable a reconocer al acreedor un derecho a compeler al deudor al cumplimiento específico se funda en algunas normas de derecho sustantivo (por referencia a ciertas leyes de las Partidas), da la impresión, que es la existencia de vías procesales de coacción (en esa época, la toma de bienes y la prisión) las que sirven de principal argumento a esa posición favorable.

$3^{\circ}$ La posibilidad de emplear estas vías procesales de apremio es, al parecer, admitida en la primera mitad del siglo XIX. Pero, esta posibilidad desaparece en la segunda mitad del siglo XIX. En este sentido, puede discutirse si la posibilidad de compeler al deudor al cumplimiento fue eliminada con la entrada en vigor de la Ley de enjuiciamiento de 1855 . En cambio, sí es claro que la Ley de enjuiciamiento civil de 1881 no contempló esa posibilidad. La Ley de enjuiciamiento civil de 1881 sólo contempló, como únicas vías de ejecución de obligaciones de hacer, el que la prestación se mande ejecutar a costa del deudor (hacer no personalísimo) y la indemnización de perjuicios (hacer personalísimo).

\section{BiBLIOGRAFÍA}

Álvarez MarTínez, Cirilo, Instituciones de derecho civil (Valladolid, Imprenta de Julián Pastor, 1840).

ÁlvareZ, José María, Instituciones de derecho real de España (Madrid, Imprenta de Repullés, 1829).

Carballo Piñeiro L., Aspectos históricos de la ejecución de condenas no dinerarias (2a

primera parte reproduce el artículo 1144 Code, el que debe leerse en relación con su artículo 1142. Además, apunta García Goyena que "el artículo primitivo del proyecto venía conforme al 1142 francés, pero sufrió contradicciones, y el resultado fue no resolver esta cuestión con la debida claridad; sin embargo [...] posteriormente [...] decidió la Comisión que no pueda ser compelido el deudor para hacerlo por sí mismo en el sentido del artículo francés" (cfr. Concordancias, 1852, III, pp. 46-47). Como ya se ha dicho, el mismo autor destaca que la solución del Derecho Patrio (por referencia a ciertas leyes de las Partidas) es más clara, y que admite la posibilidad de compeler al deudor (véase la nota 7).

${ }^{50}$ Conviene apuntar que la posibilidad de compeler al deudor mediante el uso de ciertas vías procesales de apremio, a fin de que realice la prestación de hacer debida, es una posibilidad que reaparecerá en el Derecho procesal español más de un siglo después, con la entrada en vigor de la Ley de enjuiciamiento civil del año 2000. En efecto, una de las principales novedades de esta Ley, en materia de ejecución, es la incorporación al Derecho español de la astreinte o multa coercitiva (art. 699 y ss. LEC 2000). Sobre ello, sin embargo, no corresponde tratar en este trabajo. 
Parte): del periodo visigodo a nuestros días, en Dereito, 12 (Santiago de Compostela, 2003) 1, pp. 7-36.

Coronas, S. M., Hevia Bolaños y la Curia Philipica, en Anuario de Historia del Derecho español, 77 (Madrid, 2007).

De Asso, Ignacio - De Manuel, Miguel, Las instituciones del derecho civil de Castilla (5 a edición, Madrid, s. 1., 1792).

De Castro y Bravo, Federico., Derecho civil de España (Instituto de Estudios Políticos, Madrid, 1955).

De Hevia Bolaños, La Curia Philipica. Reimpresión oficial, ordenada por el Supremo Consejo de Castilla (Madrid, 1797).

DeL VISO, Salvador, Lecciones elementales de historia y de derecho civil, mercantily penal de España (Valencia, Imprenta de José Mateo Garín, 1860).

Elías, José Antoni - De Ferrater, Esteban, Manual del derecho civil vigente en Cataluña (2a edición, Barcelona, Imprenta de Ramírez, 1864).

ESCRICHE, Joaquín, Diccionario razonado de legislación y jurisprudencia ( $3^{a}$ edición, Madrid, Librería de la Sra. Viuda e hijos de don Antonio Calleja, editores, 1847).

FALCÓN Y OZCOIDI, Modesto, Exposición doctrinal del derecho civil español, común y foral: según las leyes escritas, la jurisprudencia de los tribunales y la opinión de los escritores (Salamanca, Establ. Tipográfico de D. Vicente Oliva, 1878), II.

Fernández de BujÁn, Antonio, Ciencia jurídica europea y derecho comunitario: "ius romanun", "ius commune", "Common Law", "Civil Law" en Revista General de Derecho Romano, 10 (2008).

Fernández de la Hoz, José María, Código civil redactado con arreglo a la legislación vigente (Madrid, Imprenta de D. Eusebio Aguado, 1843).

Fernández Rodríguez, Antonio, Grandes directrices y principios informadores del Código Civil. Estimación conjunta, en Ministerio DE JustiCIA, El centenario del Código Civil en el Tribunal Supremo (Madrid, Centro de Publicaciones, 1989).

Fernández-Ballesteros López, Miguel Ángel, La ejecución forzosa y las medidas cautelares (Madrid, Irgium, 2001).

García del Corral, Ildefonso, Cuerpo del derecho civil romano (Barcelona, Jaime Molina, editor, 1889).

García Goyena, Florencio, Concordancias, motivos y comentarios del Código civil español (Madrid, Imprenta de la Sociedad Tipográfica-Editorial, 1852).

Gómez de la Serna, Pedro - Montalbán, Juan Manuel, Elementos del derecho civily penal de España (1 $1^{\mathrm{a}}$ edición, Madrid, s. l., 1841 y 7a edición, Madrid, s. 1., 1865), II.

Gómez de la Serna, Pedro, Curso histórico exegético del derecho romano comparado con el español ( 1 a edición, Madrid, Imprenta de la Compañía de Impresores y libreros del Reino, 1850), II.

Gutiérrez Fernández, Benito, Códigos o estudios fundamentales sobre derecho civil español, tratado de las obligaciones (Madrid, Imprenta de la Sra. V. e hijas de don Antonio Peñuelas, 1869).

Gutiérrez, Joseph Marco, Compendio de las varias resoluciones de Antonio Gómez (Madrid, Imprenta de Benito Cano, 1789).

GuZMÁn BRITO, A., La promesa obligacional en las partidas como sede de la doctrina general de las obligaciones, en Revista Chilena de Derecho, 34 (Santiago, 2007) 3.

Hernández de la Rúa, Vicente, Comentarios a la Ley de Enjuiciamiento civil (Madrid, Imprenta del Boletín de Jurisprudencia, 1856). 
Hernández de la Rúa, Vicente, Lecciones de derecho español (Madrid, Imprenta de don Salvador Albert, 1838).

Manresa y Navarro, José María - Reus y García, José, Ley de Enjuiciamiento Civil comentada y explicada (Madrid, Imprenta de la Revista de Legislación y Jurisprudencia, 1869).

MARTI, Ramón, Tratado elemental del derecho civil romano y español (Barcelona, Imprenta de Joaquín Verdaguer, 1838).

Martínez Marina, Francisco, Ensayo histórico-crítico sobre la antigua legislación y principales cuerpos legales de los reynos de León y Castilla (Madrid, Imprenta de la hija de Joaquín Ibarra, 1808).

Martínez Marina, Francisco, Juicio crítico de la Novísima Recopilación (Madrid, Imprenta de don Fermín Villalpando, 1820).

Ministerio de Gracia y Justicia, Colección legislativa. Sentencias del Tribunal Supremo, Edición oficial (Madrid, 1983).

Moreno Catena, Víctor, Algunos problema de la ejecución forzosa, en Anuario de la Facultad de Derecho de la Universidad Autónoma de Madrid, 5 (Madrid 2001).

RodríguEZ, Juan María, Elementos de derecho civil, penal y mercantil de España (Madrid, Imprenta de T. Fortanet, 1861), I.

SALA, Juan, Ilustración del derecho real de España (Valencia, Imprenta de Joseph de Olga, 1803).

SÁnCHeZ de Molina Blanco, J., El derecho civil español, en forma de código (Madrid, Imprenta de D. J. L Viscaíno - D. Manuel Minuesa, 1871).

SCAEvola, Quintus Mucius, Código civil comentado y concordado extensamente (Madrid, Imprenta de Ricardo Rojas, 1893-1915).

Sempere y Guarinos, Juan, Historia del derecho español (Madrid, Imprenta Nacional, 1822).

Verdera Server, Rafael, El cumplimiento forzoso de las obligaciones (Bolonia, Publicaciones del Real Colegio de España, 1995).

Verlanga HuerTa, Fermín, El derecho civil universal por aphorismos (Madrid, Imprenta de Tenes, 1843). 
